\title{
A study of $\mathrm{CO}_{2}$ emission reduction due to transportation activities in Brebes district through road repair
}

\author{
Fajar Mubarok ${ }^{1, *}$, Dewi Handayani ${ }^{2}$, and Syafi ' ${ }^{2}$ \\ ${ }^{1}$ Student of Master Program of Civil Engineering, Universitas Sebelas Maret, Surakarta, Indonesia \\ ${ }^{2}$ Lecturer of Master Program of Civil Engineering, Universitas Sebelas Maret, Surakarta, Indonesia
}

\begin{abstract}
Global climate change has prompted the Government of the Republic of Indonesia to commit to an active role and participation in the attempt of reducing Greenhouse Gas (GRK) emission through a national action program. One of the biggest sectors contributing in the production of GRK is transportation. Meanwhile, the condition of roads also affect the speed of vehicles. This study analyzed the relationship between road condition and travel speed, and the resulting $\mathrm{CO}_{2}$ emission. This research was conducted by taking some class III roads in Brebes as samples. The stages of this study include assessing the road condition by using the PCI method, calculating the average speed of vehicle on each sample road, and from the data of travel speed, the value of $\mathrm{CO}_{2}$ emission was then calculated using IPCC method. The result of this study indicated that the road condition is the factor that affects the travel speed. Increasing the value of PCI by 10 points from the lowest value will reduce $\mathrm{CO}_{2}$ emissions by $3.36 \%$ for gasoline-fueled vehicles. This research suggests improving the road condition in Brebes district in order to support Local Action Plan for Greenhouse Gas Emissions Reduction.
\end{abstract}

\section{Introduction}

Global climate change has prompted the Government of Republic of Indonesia to commit to an active role and participation in the attempt of reducing Greenhouse Gas (GRK) emission through a national action program. One of the biggest sectors contributing in the production of GRK is transportation. The provincial government of Central Java is targeting $12.5 \% \mathrm{CO}_{2}$ emission reduction from the transportation sector [1]. Emission from road sectors have contributed a large proportion as compared with non-road sectors (railway) [2]. The increasing number of motor vehicles has lead to an increase of fuel consumption. Increasing fuel consumption required in the combustion process of the engine, will certainly have an impact on increasing levels of exhaust emissions [3].

Traffic congestion and frequent stops in the flow of traffic has an impact on the increase of air pollution caused by emissions of motor vehicle exhaust [4]. As the issues of society, environment, and energy caused by traffic congestion become worse, improving the

* Corresponding author: fadjarmubarok@student.uns.ac.id 
sustainability of the urban transportation system is nowadays an urgent concern of transportation network management [5]. 80.22\% - 92.00\% pollutants in the air come from motor vehicles [6]. Load emissions obtained from the number of vehicles concludes that the gasoline vehicles will generally produce higher CO emissions than diesel vehicles [7]. Truck / pickup type vehicles also contribute to the production of 292 tons/year of $\mathrm{NO}_{2}$ gas [8]. In addition, the results of a research conducted in Denpasar, Bali shows that total road length in Denpasar is $648.49 \mathrm{~km}$ and lead to 283,650.43 tons/year $\mathrm{CO}_{2}$ emissionss in 2011. Excessive $\mathrm{CO}_{2}$ is the cause of greenhouse gas (GRK) effects that trigger global warming and climate change [9].

On the other hand the road roughness, road conditions and horizontal geometric design also affect the speed of vehicles. The relationship between pavement roughness and vehicle emissions is nonlinear. Rougher road surfaces can lead to higher vehicle emissions [10]. The comparison between very poor road conditions and excellent road conditions indicates a $55 \%$ decrease in vehicle speed and a $2.49 \%$ increase in average vehicle emissionss on very poor road conditions [11]. Smooth road segments normally allow drivers to reach higher speeds and maintain it with less acceleration. Additionally, smoother segments required less time to cover the same distance, so emissions per length were lower. It was also observed that low mean speed produced higher $\mathrm{CO}_{2}$ emission rates and it increased even more on roads with high speed dispersal [12].

Due to the fact that road condition affect the speed of vehicles on the road and impact $\mathrm{CO}_{2}$ emission, further research is needed. This study aims to obtain the relationship between $\mathrm{CO}_{2}$ emission from vehicle activity and urban road condition.

\section{Method}

This research was conducted by taking 6 samples of urban road segments (class III C) in Brebes district. The stages of this research are: assessing road condition using the Pavement Condition Index method (PCI), calculating the fuel consumption of each type of vehicle from the survey results using the equation of Pacific Consultant International (PCI) with the speed of travel as the variable, and calculating $\mathrm{CO}_{2}$ emissions using the equation from International Panel on Climate Change (IPCC). The correlations between road conditions and travel speed as well as the correlation between travel speed and $\mathrm{CO}_{2}$ emission were analyzed using regression analysis.

\subsection{Assessment using pavement condition index ( $\mathrm{PCl})$}

The assessment of pavement condition using the PCI method was developed by the US Army. The Pavement Condition Index is the level of pavement surface condition. PCI is a numeric index which value ranging from 0 to 100. A value of 0 indicates that the pavement is a failure, and a value of 100 indicates that the pavement is excellent [13]. PCI is based on visual condition surveys. Road damage data observed include the type of damage, severity, and dimension of damage that are then calculated to obtain the Deduct Velue (DV) and determine the value of Corrected Deduct Value (CDV), then the PCI value is obtained by subtracting 100 by the total CDV. The PCI value of a single path is the average of the PCI values of each segment

\subsection{Calculation of fuel consumption}

Calculation of fuel consumption involves a calculation model developed by the Pacific Consultant International (PCI). Travel speed becomes the variable in fuel usage. Vehicles 
that move slowly will increase fuel consumption. The data of travel speed is obtained by a survey using a vehicle model method [14].

\subsection{Vehicle emission calculation using IPCC method}

In this study the calculated emissions is $\mathrm{CO}_{2}$, because it is a compound that causes the greenhouse gas effect. To calculate $\mathrm{CO}_{2}$ emission, some data is required, such as number of vehicles, vehicle type, fuel type, emission factor, and level of fuel consumption for each type of vehicle. The data on the number and type of vehicles is obtained through manual traffic surveys [15]. To facilitate the analysis process, the survey results of each type of vehicle are grouped into 3 groups of motor vehicles according to MKJI 1997; motorcycle (MC), low vehicle (LV) and heavy vehicle (HV) [16]. Low vehicles are divided into two types based on the type of fuel used, namely either diesel or gasoline. The emission factor used in the calculation of $\mathrm{CO}_{2}$ emissions is the national emission factor according to the Minister of Environment Regulation No. 12/2010 on Air Pollution Control in the Region [17]. Meanwhile the level of fuel consumption is obtained from the calculations using a model developed by Pacific Consultant International (PCI).

\section{Results and discussions}

\subsection{Pavement condition index (PCI)}

The road samples used are an urban road belonging to class III C. Each sample of road is divided into segments, each with length of $100 \mathrm{~m}$. Each sample is grouped into 7 categories of damage levels: excellent, verry good, good, fair, poor, very poor and failed. PCI calculation results are shown in table 1.

Table 1. PCI calculation results of each road.

\begin{tabular}{|c|c|c|c|c|c|}
\hline \multirow{2}{*}{ No } & \multirow{2}{*}{ Roads } & Length & width & \multirow{2}{*}{$\begin{array}{c}\text { PCI } \\
\text { Average }\end{array}$} & \multirow{2}{*}{ Damage levels } \\
\hline & & m & $\mathbf{m}$ & & \\
\hline 1 & J1. Songgom & 9200 & 5 & 20,4 & VERY POOR \\
\hline 2 & Jl. Pramuka & 1200 & 5 & 37,5 & POOR \\
\hline 3 & Jl. Abimanyu & 1000 & 5 & 41,4 & FAIR \\
\hline 4 & Jl. Ahmad Dahlan & 1200 & 5 & 65,7 & GOOD \\
\hline 5 & Jl. Ronggowarsito & 3500 & 5 & 79,5 & VERY GOOD \\
\hline 6 & Jl. Sultan Agung & 2500 & 6 & 83,6 & VERY GOOD \\
\hline
\end{tabular}

\subsection{Impact of road damage on travel speed}

The travel speed data is obtained by conducting a survey based on the survey guides and traffic time calculation from the Directorate General of Highways. The speed of each vehicle type is averaged and presented in table 2 . The correlation between road surface conditions and average vehicle speed was statistically developed to measure the relationship between road conditions and the speed of all vehicle types as presented in Figure 1. The graph on Figure 1 clearly shows that all types of vehicles show a relationship between road damage and their speed of travel. There is an up to $57 \%$ decrease of speed on very poor road conditions compared to on very good road conditions. 
Table 2. Average travel speed for each road condition.

\begin{tabular}{|c|l|l|l|l|l|l|l|l|c|}
\hline \multirow{2}{*}{ No } & Type of vehicle & \multicolumn{6}{|c|}{ PCI Value } & \multirow{2}{*}{ Correlation } & \multirow{2}{*}{$\boldsymbol{R}^{\mathbf{2}}$} \\
\cline { 3 - 8 } & and speed (km/h) & $\mathbf{2 0 , 3 8}$ & $\mathbf{3 7 , 5 0}$ & $\mathbf{4 1 , 4 0}$ & $\mathbf{6 5 , 6 7}$ & $\mathbf{7 9 , 4 9}$ & $\mathbf{8 3 , 6 0}$ & & \\
\hline 1 & MC & 22,47 & 25,24 & 26,02 & 31,71 & 35,04 & 36,27 & y $=4,455 \mathrm{x}-76,58$ & 0,993 \\
\hline 2 & LV (Gasoline) & 19,04 & 23,06 & 24,10 & 28,51 & 31,84 & 34,67 & $\mathrm{y}=4,296 \mathrm{x}-60,76$ & 0,984 \\
\hline 3 & LV (Diesel) & 15,89 & 18,21 & 19,25 & 23,15 & 26,13 & 28,30 & $\mathrm{y}=5,194 \mathrm{x}-58,67$ & 0,981 \\
\hline 4 & HV & 13,00 & 15,19 & 16,25 & 20,13 & 23,82 & 25,07 & $\mathrm{y}=5,154 \mathrm{x}-42,78$ & 0,984 \\
\hline
\end{tabular}

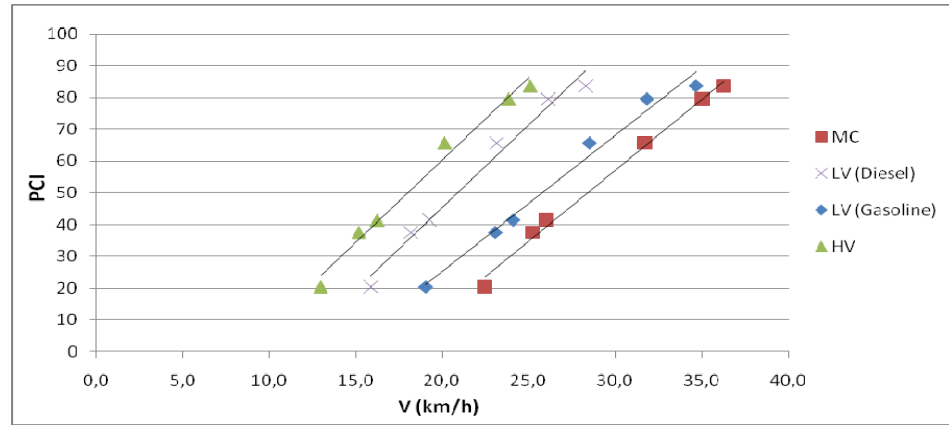

Fig. 1. Correlation of travel speed and road surface conditions.

\subsection{Correlation of road condition and $\mathrm{CO}_{2}$ emissions}

To calculate $\mathrm{CO}_{2}$ emission, some data is required, such as number of vehicles, vehicle type, emission factor, and level of fuel consumption for each type of vehicle. $\mathrm{CO}_{2}$ emissions are calculated using methods issued by the International Panel on Climate Change (IPCC). The $\mathrm{CO}_{2}$ emission calculation results are shown in table 3 .

Table 3. $\mathrm{CO}_{2}$ emissions from each vehicle type and its relation to PCI.

\begin{tabular}{|c|c|c|c|c|c|c|c|c|}
\hline \multirow[b]{2}{*}{ Roads } & \multirow[b]{2}{*}{ PCI } & \multirow{2}{*}{$\begin{array}{l}V_{\text {average }} \\
(\mathbf{k m} / \mathbf{h})\end{array}$} & \multirow{2}{*}{$\begin{array}{c}\text { fuel } \\
\text { cons. } \\
(\mathbf{l t} / \mathbf{k m})\end{array}$} & \multicolumn{4}{|c|}{$\mathrm{CO}_{2}$ emissions $(\mathrm{g} / \mathrm{km})$} & \multirow{2}{*}{$\begin{array}{c}\text { Average } \\
(\mathrm{g} / \mathrm{km})\end{array}$} \\
\hline & & & & MC & $\begin{array}{c}\mathbf{L V} \\
\text { Gasoline }\end{array}$ & $\begin{array}{c}\mathrm{LV} \\
\text { Diesel }\end{array}$ & HV & \\
\hline Jl. Songgom & 20,4 & 17,6 & 0,376 & 60,80 & 412,60 & 1617,79 & 1732,07 & 955,81 \\
\hline Jl. Pramuka & 37,5 & 20,4 & 0,353 & 58,19 & 388,89 & 1517,06 & 1629,29 & 898,36 \\
\hline J1. Abimanyu & 41,4 & 21,4 & 0,343 & 57,30 & 378,73 & 1473,90 & 1581,94 & 872,97 \\
\hline Jl. Ahmad Dahlan & 65,7 & 25,9 & 0,309 & 55,31 & 343,23 & 1323,41 & 1417,88 & 784,96 \\
\hline Jl. Ronggowarsito & 79,5 & 29,2 & 0,282 & 52,03 & 318,65 & 1219,50 & 1277,72 & 716,98 \\
\hline Jl. Sultan Agung & 83,6 & 31,1 & 0,269 & 51,54 & 302,24 & 1150,23 & 1233,68 & 684,42 \\
\hline
\end{tabular}

From table 3, it can be observed that the PCI value of each road segment affects the average traveling speed of each vehicle type. On the other hand the relationship between speed of travel and fuel consumption is inversely proportional. Fast-moving vehicles will consume less fuel. Fuel consumption of each type of vehicle certainly affects the resulting $\mathrm{CO}_{2}$ emissions. High fuel consumption levels will result in high $\mathrm{CO}_{2}$ emissions as well.

Correlations among road conditions, travel speed and $\mathrm{CO}_{2}$ emissions are shown in Figure 2. The graphs in Figure 2 show that high PCI values lead to an increased travel speed. On the other hand, a high travel speed will result in less fuel consumption, and less fuel consumption will certainly be comparable to the $\mathrm{CO}_{2}$ emissions generated by motor vehicles. Increasing the value of PCI by 10 points from the lowest value will reduce $\mathrm{CO}_{2}$ emissionss by $3.36 \%$ for gasoline-fueled vehicles. 


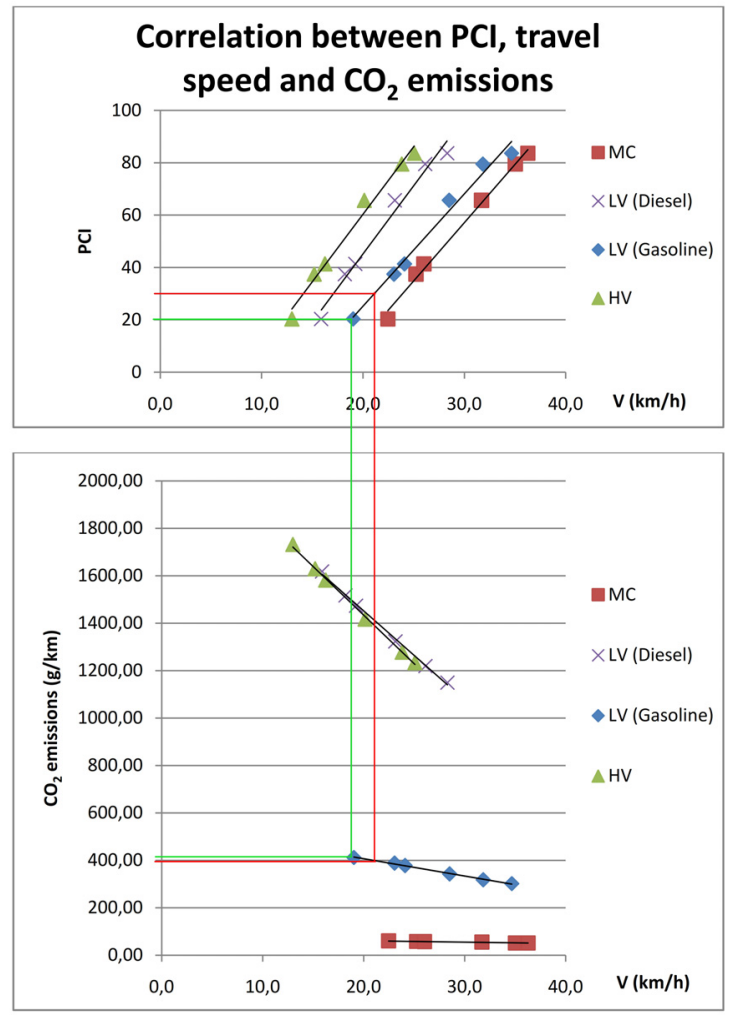

Fig. 2. Correlation between $\mathrm{PCI}$, travel speed and $\mathrm{CO}_{2}$ emissions

\section{Conclusion}

In conclusion, there is a correlation between road conditions, travel speed and production of $\mathrm{CO}_{2}$ emissions by vehicles. Road damage can affect the travel speed of vehicles. Very poor road conditions led to a $57 \%$ reduction in travel speed compared to very good road conditions. The decrease in speed leads to an increase in fuel consumption. Higher fuel consumption will cause higher $\mathrm{CO}_{2}$ emissions as well. Increasing the value of PCI by 10 points from the lowest value will reduce $\mathrm{CO}_{2}$ emissions by $3.36 \%$ for gasoline-fueled vehicles.

\section{References}

1. Central Java governor regulation no. 43 on RAD-GRK of Central Java Province for 2012-2020. (2012)

2. Sa'duddin, M.P. Hadi. Beban Emisi Sektor Transportasi di Kota Yogyakarta. The $18^{\text {th }}$ FSTPT International Symposium, Unila. (2015)

3. D. Handayani, Y.I. Jaya, and S.J. Legowo. Analisis Emisi Gas Buang Akibat Mobil di Kampus Universitas Sebelas Maret. Matriks Teknik Sipil Vol. 5, 3. (2017)

4. G. Fitri. Tingkat Polusi Udara Dari Emisi Gas Buang Kendaraan Bermotor Berdasarkan Volume Lalu Lintas. Jurnal Reaksi (Journal of Science and Technology). Vol. 7 16. (2009) 
5. D. Handayani, H.C. Putri, and A.M.H. Mahmudah. Logit and probit model in toll sensitivity analysis of Solo-Ngawi, Kartasura-Palang Joglo segment based on Willingness to Pay (WTP). IOP Conference Series: Earth and Environmental Science. Vol. 109, 1. IOP Publishing. (2017)

6. S.L. Sengkey, F. Jansen, S. Wallah. Tingkat Pencemaran Udara CO Akibat Lalu Lintas dengan Model Prediksi Polusi Udara Skala Mikro. Jurnal Ilmiah Media Engineering. Vol. 1, 2. (2011)

7. S.A.M.P. Ofrial, E. Ahyudanari, A.D. Syafei,. Estimation on the increasing value of CO based on the vehicle growth in Surabaya. Procedia - Social and Behavioral Sciences $227410-416$ ( 2016 )

8. A.Z. Maulana. Analisis Beban Pencemar Udara $\mathrm{SO}_{2}, \mathrm{NO}_{2}$ dan $\mathrm{HC}$ Dengan Pendekatan Line Source Modeling. Widyariset, Vol. 15, 3. (2012)

9. N. Nurdjanah. Emisi $\mathrm{CO}_{2}$ Akibat Kendaraan Bermotor Di Kota Denpasar. Jurnal Penelitian Transportasi Darat, Vol. 17 1. (2015)

10. Qing Li, Fengxiang Qiao, Lei Yu. Clustering Pavement Roughness Based on the Impacts on Vehicle Emissions and Public Health. J Ergonomics. (2015)

11. A. Setyawan, I. Kusdiantoro, Syafi'i. The Effect Of Pavement Condition on Vehicle Speeds and Motor Vehicles Emissions. Procedia Engineering 125 424-430 (2015)

12. D. Llopis-Castelló, A.M Pérez-Zuriaga, F.J Camacho-Torregrosa, A. García. Impact of horizontal geometric design of two-lane rural roads on vehicle $\mathrm{CO}_{2}$ emissions. Transportation Research Part D 59 46-57 (2018)

13. M.Y. Shahin. Pavement Management for Airports, Roads, and Parking Lots. Chapman $\&$ Hall. New York. (2002)

14. Directorate General of Highways. Survey Guide and Time Travel Traffic Calculations. No. 001/T/BNKT/1990. (1990)

15. Department of Settlement and Regional Infrastructure. Survey on Traffic Manually. Pd. T-19-2004-B. (2004)

16. Directorate of Urban Road Development. MKJI. (1997)

17. Ministry of Environment. Technical Guidelines for Preparation of Urban Air Pollutant Emission Inventory. (2013) 